\title{
Missed Reason
}

National Cancer Institute

\section{Source}

National Cancer Institute. Missed Reason. NCl Thesaurus. Code C93597.

The text and/or code that describes the rationale behind why an activity is not done. 